\title{
Materi Sejarah dalam Buku Teks Muatan Lokal Pendidikan Multikultur Kalimantan Barat
}

\author{
EKA JAYA PUTRA UTAMA \\ Pendidikan Sejarah STKIP PGRI Pontianak \\ e-mail : jaya_240183@yahoo.co.id
}

\begin{abstract}
Abstrak
Penelitian ini bertujuan untuk mengetahui (1) Tujuan dimunculkannya buku teks muatan lokal pendidikan multikultur Kalimantan Barat; (2) Penyajian materi dalam buku teks muatan lokal pendidikan multikultur Kalimantan Barat; (3) Materi sejarah dalam buku teks muatan lokal pendidikan multikultur Kalimantan Barat. Penelitian diskriptif kualitatif dengan studi kasus tunggal dan strategi penelitian dalam bentuk terpancang. Hasil penelitian menunjukkan bahwa dimunculkannya buku teks muatan lokal pendidikan multikultur Kalimantan Barat: (1) Untuk rekonsiliasi konflik melalui jalur pendidikan sekaligus mengenalkan kembali kebudayaan etnis di Kalimantan Barat; (2) Masih memiliki kelemahan dan kekurangan mengenai kelogisan sajian materi yang menjelaskan materi melalui cerita rakyat (folklore), tidak menunjukkan glosarium, indeks, ketepatan tata bahasa, ketidaksesuaian antara materi dengan ilustrasi dan penulisan daftar pustaka; (3) Materi sejarah adalah sejarah lokal Kalimantan Barat dan sejarah kebudayaan etnis Dayak, Melayu, Tionghoa dan Madura.
\end{abstract}

\section{Kata kunci : Materi Sejarah, Buku Teks Muatan Lokal, Pendidikan Multikultur}

\begin{abstract}
This research aims to know (1) the purposes of publishing local content textbooks of multicultural education in West Kalimantan; (2) the presentation of the materials in the textbook local content of multicultural education in West Kalimantan; and (3) the material of history in textbooks local content of multicultural education in West Kalimantan. This research is descriptive qualitative research with a single case study and research strategies in the form of embedded. The results show that the publication of local content textbooks of multicultural education in West Kalimantan: (1) aims to reconciliate conflict through education and introducing the ethnic cultures in West Kalimantan; (2) has weaknesses and deficiencies regarding materials that explain the logic grain material through folklore, des not show a glossary, index, grammatical correctness, the mismatch between the material with illustrations and writing a bibliography; (3) presents history materials of local history and cultural history of West Kalimantan Dayaks, Malays, Chinese and Madura.
\end{abstract}

Keywords: History Materials, Local Content Textbook, Multicultural Education 


\section{PENDAHULUAN}

Buku teks merupakan bagian yang tidak bisa terpisahkan dari satuan pembelajaran di kelas. Buku teks pelajaran menjadi salah satu sumber belajar guna memperoleh informasi selain guru di kelas. Dalam rangka pelaksanaan pengawasan dan peningkatan mutu pendidikan dasar dan menengah melalui standarisasi buku teks pelajaran, telah ditetapkan Peraturan Menteri Pendidikan Nasional Nomor 11 tahun 2005 tentang pentingnya buku teks pelajaran bagi peserta didik (BNSP, 2006: v). Dengan demikian, buku teks yang digunakan oleh siswa maupun guru harus diperiksa terlebih dahulu isi, materi, bahasa, dan kualitas buku sehingga ketika digunakan akan memperoleh informasi dan pengetahuan yang yang sesuai dengan kebutuhan siswa maupun guru dan tingkatan kelasnya.

Kurikulum muatan lokal merupakan salah satu bagian dari kurikulum yang berlaku saat ini, istilah muatan lokal dalam dunia pendidikan di Indonesia secara resmi mulai tahun 1987, melalui Keputusan Menteri Pendidikan dan kebudayaan Nomor 0412/U/1987 tanggal 11 Juli 1987, tentang muatan lokal. Kurikulum atau mata pelajaran muatan lokal pada awalnya bukan mata pelajaran yang berdiri sendiri, melainkan materi pelajaran lokal yang dimasukkan ke dalam berbagai bidang studi yang relevan.

Sejak diberlakukannya kurikulum tahun 1994, muatan lokal menjadi mata pelajaran yang berdiri sendiri, atau tidak lagi diintegrasikan pada mata pelajaran lainnya. Konsep muatan lokal tidak lagi sama seperti tahun 1987, konsep muatan lokal di sini maksudnya adalah bentuk penyelenggaraan pendidikan yang bersifat desentralisasi, sebagai upaya pemerintah untuk lebih meningkatkan relevansi terhadap kebutuhan daerah yang bersangkutan Kurikulum tahun 1994 muatan lokal sudah menjadi bidang studi yang berdiri sendiri, baik bidang studi wajib maupun bidang studi pilihan, atau lebih dikenal dengan mata pelajaran muatan lokal wajib dan mata pelajaran muatan lokal pilihan.

Pelaksanaan rekonstruksi sosial, sekolah harus berusaha melengkapi sarana penunjang yang tersedia guna memberikan pengetahuan kepada peserta didik, agar nantinya bisa menangani hambatan-hambatan yang terjadi di masyarakat, salah satunya adalah buku teks. Sekolah berusaha memberikan penerangan dan melatih kemampuan untuk melihat dan mengatasi hambatan-hambatan yang dihadapi, meningkatkan kemampuan memecahkan masalah-masalah yang dihadapi (Nana Syaodih Sukmadinata, 2000 : 95).

Buku teks pelajaran merupakan salah satu sumber yang digunakan oleh guru sebagai bahan ajar dalam melaksanakan proses pembelajaran. Guru dituntut untuk memahami isi materi yang tercantum dalam buku teks pelajaran, karena pada umumnya buku teks pelajaran yang digunakan oleh guru ditulis oleh orang lain atau penulis buku dari suatu penerbit. Penulis buku biasanya mencoba menginterpretasikan sendiri deskripsi materi yang harus ditulis berdasarkan standar kompetensi dan kompetensi dasar sebagaimana yang tercantum dalam standar isi.

Buku teks sebagai sumber belajar bagi peserta didik juga menjadi sumber bahan ajar oleh guru dalam proses belajar mengajar. Secara formal biasanya buku teks dikeluarkan oleh dinas pendidikan ataupun lembaga pendidikan yang berkompeten. Pelajaran muatan lokal menggunakan buku teks dalam membantu guru untuk mengajar di kelas, Selain itu juga menawarkan berbagai macam materi yang tentunya menggunakan beragam sumber yang berasal dari buku teks.

Sejalan dengan paradigma pendidikan yang akhir-akhir ini telah mengalami pergeseran yakni guru tidak lagi semata-mata sebagai pusat pembelajaran kepada peserta didik namun peserta didik perlu diberikan peluang untuk mencari dan mendapatkan informasi yang seluas-luasnya dari berbagai macam sumber.

Beragamnya buku teks muatan lokal yang digunakan oleh sekolah-sekolah diantaranya buku teks muatan lokal agro pertanian, bahasa Inggris, bahasa daerah, komputer, pendidikan multikultural. Dari banyaknya buku teks yang ditawarkan belum tentu semuanya dapat dijadikan pedoman ataupun acuan 
bagi guru sebagai pegangan untuk mengajar karena harus melewati beberapa kreteria diantaranya penulisan, bahasa, tingkat pemahaman, isi, kedalaman materi, ilustrasi. Dengan demikian sekolah dan guru harus cermat memilih dan menggunakan buku teks sebagai pedoman untuk mengajar.

Dengan beragam buku teks muatan lokal di Kalimantan Barat, terdapat buku teks muatan lokal pendidikan multikultur untuk SMP yang mempelajari nilai keberagaman budaya, adat istiadat, bahasa daerah, kesenian daerah dari ernis yang ada. di Kalimantan Barat. Untuk itu perlu dikaji apakah materi sejarah ada termuat di dalam buku teks muatan lokal pendidikan multikultur Dari latar belakang pemikiran di atas, penelitian ini bertujuan untuk mendeskripsikan tentang (1). Tujuan dimunculkannya buku teks muatan lokal pendidikan multikultur Kalimantan Barat (2). Penyajian materi dalam buku teks muatan lokal pendidikan multikultur Kalimantan Barat (3). Materi sejarah yang ada dalam buku teks muatan lokal pendidikan multikultur Kalimantan Barat.

\section{METODE}

Penelitian ini menggunakan metode kualitatif dengan studi kasus terpancang (embedded research). Penelitian dilakukan di kota Pontianak dan Pahauman Propinsi Kalimantan Barat. Sumber data terdiri atas informan (Tim ANPRI, guru-guru muatan lokal, stakeholder dan siswa), dokumen (Buku Teks Muatan Lokal Pendidikan Multikultur Kalimantan Barat SMP/MTs). Teknik pengumpulan data menggunakan teknik wawancara mendalam dan content analysis. Validitas data menggunakan trianggulasi sumber dan trianggulasi metode. Analisis data menggunakan analisis interaktif dengan tiga tahapan analisis, yakni reduksi data, penyajian data, dan penarikan simpulan yang berinteraksi dengan pengumpulan data secara siklus

\section{HASIL DAN PEMBAHASAN}

Upaya mencapai tujuan rekonsiliasi konflik dan penanaman kembali pengetahuan budaya lokal kepada peserta didik maka gabungan dari beberapa organisasi yakni, Institut Dayakologi, Lembaga Gemawan, Sekretariat Segerak Pancur Kasih, Mitra Sekolah Masyarakat (MiSEM), Badan Koordinasi Koperasi Kredit Daerah (BK3D) Kalimantan Barat dan PEK- Pancur Kasih. Dari forum inilah muncul kesepakatan untuk mendirikan aliansi strategis yang dinamakan ANPRI (Aliansi untuk Perdamaian dan Rekonsiliasi).

Isu-isu yang dimunculkan dalam ANPRI ini adalah mencari sebab-sebab yang memicu konflik, yang diantaranya ketidakadilan, penindasan kaum kaya terhadap kaum miskin karena kebijakan yang salah.

Oleh karena itu, maka budaya merupakan faktor yang menyebabkan kesalahan tersebut. Kekerasan sudah menjadi semacam budaya dalam kehidupan di masyarakat, maka harus dilawan melalui budaya juga yakni budaya anti kekerasan (non violence).

Ada banyak wadah untuk menanamkan budaya damai, antara lain media massa dan lembaga pendidikan. Pendidikan formal merupakan salah satu wadah yang baik untuk menanamkan budaya anti kekerasan, budaya menghormati dan menghargai perbedaan.

Proses pelaksanaan menanamkan budaya damai dan anti kekerasan maka yang dipilih ANPRI adalah Sekolah Menengah Pertama (SMP). Adapun alasan SMP yang dipilih; (a). secara psikologis anak usia dini adalah masa-masa atau proses penanaman budaya cinta damai, hormat menghormati, menghargai orang lain akan lebih mudah, (b). tahap pemikiran anak usia dini dalam proses pemahaman materi pelajaran akan lebih baik dan (c). pembentukan jati diri manusia yang berakhlak mulia. Hal ini dilakukan atas pertimbangan, ketika muatan lokal pendidikan multikultural diterapkan pada siswa Sekolah Dasar (SD), secara penalarannya siswa terlalu sulit untuk memahami materi karena kendala bahasa dan penekanan tujuan isi buku teks yang tinggi.

Alasan tidak dimulai pada Sekolah Menengah Atas (SMA) karena faktor usia yang sudah beranjak remaja dan dewasa akan lebih sulit menanamkan nilai-nilai luhur budaya etnisitas sebab siswa-siswa SMA ban- 
yak mendapatkan berbagai macam pengaruh dari luar sehingga untuk mempelajari multikultural etnis akan dianggap biasa-biasa saja.

Proses penanaman nilai-nilai budaya merupakan sesuatu yang berat apabila usia, tingkat penalaran, psikologis manusia dan tidak dibarengi dengan sikap penduli dari manusia tersebut maka pendidikan yang dilakukan merupakan sesuatu yang sia-sia.

Pada tahap pertama ANPRI melakukan kerjasama dengan 7 sekolah swasta dengan latar belakang siswa dari 4 etnis besar di Kalimantan Barat, yakni etnis Dayak, Melayu, Madura dan Tionghoa. Ketujuh sekolah tersebut adalah SMP Santo Fransiskus Asisi (mayoritas siswa dari etnis Tionghoa), SMP Haruniyah (mayoritas siswa dari etnis Melayu), Madrasah Tsanawiyah (MTs) Nurul Alamiah (mayoritas siswa dari etnis Madura), Madrasah Tsanawiyah (MTs) Nahdatul Atfal (mayoritas siswa dari etnis Madura), SMP Santo Benediktus Pahauman (mayoritas siswa dari etnis Dayak), SMP Don Bosco Menjalin (mayoritas siswa dari etnis Dayak) dan SMP Gerpemi Tebas (mayoritas siswa dari etnis Melayu).

Tujuan diterbitkan buku teks muatan lokal pendidikan multikultur Kalimantan Barat, jelas untuk rekonsiliasi konflik melalui jalur pendidikan namun yang ditekankan adalah penanaman dan pengetahuan siswa terhadap budaya etnis lain sehingga terciptanya sikap menghargai, menghormati dan toleransi diantara siswa tersebut. Penyusunan materi muatan lokal pendidikan multikultur melalui proses yang sangat panjang. Pertama, ANPRI dan 7 sekolah mitra kerja melakukan seminar tentang mata pelajaran muatan lokal multikultur dalam konteks Kalimantan Barat.

Dari seminar yang diselenggarakan menghasilkan catatan-catatan penting yaitu, multikultural merupakan isu yang pantas diangkat dan dijadikan materi dalam muatan lokal, nilai-nilai budaya dalam multikultural mengandung unsur keluhuran yang tinggi dan harus dikenalkan dan ditanamkan dalam diri siswa sejak dini. Atas dasar itulah maka multikultural Kalimantan Barat diterima dan diangkat menjadi bagian dari materi muatan lokal.
Kelayakan isi dalam buku teks harus memperhatikan cakupan materi yang memuat pengetahuan dan sikap secara komprehensif, keluasan dan kedalaman materi. Komponen tersebut termuat dalam setiap pokok bahasan materi pada buku teks muatan lokal pendidikan multikultur Kalimantan Barat. Pada bab satu tentang pendidikan multikultur, secara rinci dan mendalam memberikan penjelaskan mengenai latar belakang lahirnya pendidikan multikultur hingga pengertian pendidikan multikultur dengan konsep dan teorinya. Misalnya, pendidikan multikultur didefinisikan pendidikan untuk dan tentang keanekaragaman budaya dengan maksud agar tercipta penghargaan, penghormatan dan penerimaan terhadap keanekaragaman budaya orang/ kelompok lain.

Pengertian tersebut sebelumnya dijelaskan dari teori multikultur, multikultural dan multikulturalisme. Dari sistematika penjelasan materi tersebut akan lebih memudahkan peserta didik memahami pengertian pendidikan multikultur.

Materi sesuai dengan perkembangan ilmu (BSNP, 2006 : 12) maksudnya adalah bahwa materi disajikan disesuai dengan perkembangan ilmu pengetahuan dan kebutuhan peserta didik menggunakan rujukan dan contoh-contoh masa kini (up to date). Buku teks muatan lokal pendidikan multikultur diciptakan karena ada hal penting yang harus disampaikan dan dipelajari oleh peserta didik yakni belajar untuk mengetahui budaya kelompok lain dan menyadarkan bahwa Kalimantan Barat memiliki keanekaragaman budaya.

Dengan adanya proses pembelajaran yang diaplikasikan dengan contoh dalam keseharian peserta didik maka tujuan pendidikan multikultur akan tercapai. Salah satu contoh yang dimaksud ada pada bab lima halaman 73, menjelaskan mengenai budaya masyarakat Melayu Kalimantan Barat.

Kegiatan bermain meriam karbit merupakan tradisi bagi masyarakat Melayu Pontianak, dengan adanya buku teks muatan lokal pendidikan multikultur Kalimantan Barat, peserta didik dijelaskan bahwa permainan tersebut memiliki makna yakni awal mula 
berdirinya kerajaan Pontianak yang dicontohkan dengan gambar dan proses pembuatan meriam karbit yang terbuat dari bambu (buluh).

Hal tersebut tentu menumbuhkan semangat dan mendorong peserta didik untuk mengetahui lebih mendalam materi buku teks muatan lokal pendidikan multikultur Kalimantan Barat. Nilai positif yang dapat dipetik dari materi buku teks muatan lokal pendidikan multikultur masyarakat Kalimantan Barat adalah memunculkan lagi keanekaragaman budaya etnis yang telah lama terlupakan sehingga membuka wawasan peserta didik untuk memiliki dan bagian dari budaya kelompok lain. Dengan demikian maka terwujud kehidupan yang sejajar walau berbeda ideologi.

Komponen kebahasaan menjadi sangat penting apabila memilih buku teks untuk sumber belajar. Kebahasaan berkaitan dengan kesesuaian dengan tingkat perkembangan berpikir peserta didik, pesan (termasuk gambar dan tabel) disajikan dalam bahasa yang lazim dalam komunikasi tulis bahasa Indonesia sehingga mudah dan langsung dipahami peserta didik (BSNP, 2006 : 15).

Pada bab enam halaman 85 menjelaskan tentang permainan barongsai dan naga oleh masyarakat Tionghoa di Kalimantan Barat, sajian materi dijelaskan dengan contoh gambar-gambar yang merupakan ungkapan bahasa simbolik dan mudah diketahui oleh peserta didik. Barongsai adalah permaianan naga yang sudah tidak asing bagi masyarakat Kalimantan Barat dan Indonesia. Bahasa yang sangat komunikatif dan interaktif mampu memotivasi peserta didik untuk merespon pesan yang disampaikan.

Kelugasan dalam menyampaikan maksud materi harus terstruktur dan tidak berbelitbelit. Keruntutan alur pikir merupakan cerminan keterkaitan isi dan kesatuan tema pada satu subbab. Penjelasan multikultur pada buku teks muatan lokal pendidikan multikultur pada dasarnya tidak sulit untuk dipahami. Namum buku teks tersebut merupakan sumber belajar maka akan sulit bagi peserta didik memahami maksud dan tujuan dari materi yang ingin disampaikan.
Bab pertama di halaman 7 yang menjelaskan pengertian pendidikan multikultur, terlebih dahulu memberikan teori mengenai multikultur dan multikulturalisme yang pada dasarnya memiliki keterkaitan maksud yakni keberagaman dalam kesejajaran budaya. Oleh karena itu lebih tepat apabila pengertian multikultur dijelaskan menggunakan sebuah teori yang sudah teruji dan terukur tingkat kepercayaannya atau kredibelitas arti sesungguhnya, sehingga sajian dalam buku teks tidak harus memaparkan banyak pandangan mengenai mulrikultur yang akan mempersulit peserta didik untuk memahaminya.

Penggunaan istilah dan simbol atau lambang sering ditemui dalam buku teks muatan lokal pendidian multikultur Kalimantan Barat. Pada bab pertama di halaman 8 yang menjelaskan pendidikan multikultur, terdapat istilah melting pot, salad bowl, yang sebenarnya tidak perlu digunakan karena penjelasan pendidikan multikultur untuk peserta didik pada tingkat pendidikan SMP belum mampu mencerna maksud teori atau istilah tersebut. Walaupun sebenarnya penyampaian istilah itu penting guna mensistematiskan alur pikir terciptanya multikulturalisme.

Tidak semua sajian materi sepenuhnya menggunakan bahasa Indonesia dengan baik dan benar atau Ejaan Yang Disempurnakan (EYD). Bahasa daerah dan penggunaan istilah daerah merupakan nilai tambah dari materi dalam buku teks muatan lokal pendidikan multikultur Kalimantan Barat.

Alasannya adalah pengenalan budaya lokal apabila tidak memunculkan istilah lokalitas etnis maka jauh dari pemahaman tentang multikultur. Salah satunya materi dimaksud disajikan pada bab dua halaman pada halaman 27 untuk menjelaskan gambaran etnis Dayak dalam keterbukaan dengan bahasa Dayak Kanayatn berbunyi "ahe gik talino, asu' pun dibare makatn" artinya apalagi manusia, anjing pun diberi makan.

Pada bab empat yang menjelaskan tentang pesta panen masyarakat Dayak Kalimantan Barat dengan berbagai macam istilah karena setiap daerah penyebutannya berbeda tetapi maknanya sama, seperti Dange 
(pesta panen padi Dayak Kayaan), Ngabayotn (pesta panen padi Dayak Salako), Nyabakng (pesta panen padi Dayak Bakati') dan Naik Dango (pesta panen padi Dayak Kanayatn).

Catatan yang paling penting ketika meyajikan istilah pada setiap pokok materi dalam upaya memperjelas bahasan adalah konsistensi penggunaan istilah dan simbol atau lambang.

Dengan demikian tidak akan mengganggu pemahaman konsep, prinsip, asas atau sejenisnya pada antar bagian dalam buku teks muatan lokal pendidikan multikultur Kalimantan Barat. Dalam teknik penyajian yang menjadi catatan penting adalah sistematika sajian tiap bab harus utuh atau lengkap (BSNP, 2006 : 17). Sementara buku teks muatan lokal pendidikan multikultur Kalimantan Barat, pada bab pertama tidak menampilkan pendahuluan sebagai pengantar namun dijelaskan dalam materi sehingga terintegrasi pengantar materi dan materi pokok.

Kelogisan sajian materi dalam buku teks muatan lokal pendidikan multikultur Kalimantan Barat, pada masing-masing bab mencerminkan pola pikir deduktif dan induktif. Keruntutan sajian konsep ketika dikaji mulai dari bab pertama hingga bab tujuh lebih cenderung pada materi yang sederhana ke kompleks atau dari yang materi yang sudah dikenal sampai yang belum dikenal oleh siswa. Walau demikian terdapat beberapa materi yang disampaikan melalui cerita rakyat (folklore), misalnya pada bab empat mengenai pesta panen masyarakat Dayak Kalimantan Barat di halaman 67, menjelaskan bahwa urutan pesta padi salah satunya selalu dengan memanggil roh padi agar bersemayam menunggu musim tanam berikutnya.

Dari penjelasan tersebut menunjukkan bahwa banyak cerita rakyat (folklore) yang dijadikan simbol sebagai kekuatan untuk mengatakan bahwa kegiatan manusia tidak dapat dilepaskan dengan roh nenek moyang orang Dayak. Keseimbangan sajian materi antar bab dan antar subbab sudah berurutan. Sementara tuntutan dalam komponen kebahasaan dijelaskan bahwa bahasa yang digunakan, baik untuk menjelaskan konsep maupun aplikasi konsep, sesuai tingkat perkembangan kognitif peserta didik pada tiap-tiap satuan pendidikan (BSNP, 2006 : 15).

Buku teks muatan lokal pendidikan multikultur Kalimantan Barat diperuntukan bagi siswa SMP, walaupun untuk tingkatan satuan pendidikan dasar, bahasa dan konsep aplikasinya harus mampu memberi penjelasan materi yang baik. Di samping itu juga istilahistilah asing dan bahasa daerah kerap digunakan, namun satu hal positif karena peserta didik diperkaya dengan konsep yang belum diketahui sebelumnya.

Pendukung Penyajian Materi meliputi kesesuaian ilustrasi yang disajikan pada buku teks muatan lokal pendidikan multikultur, cukup memperjelas materi. Pada setiap bahasan selalu disertai gambar yang sesuia dengan materi yang dijelaskan. Penggunaan tabel juga ditampilkan dalam pembahasan gambaran etnis Dayak yang menjelaskan kelompok-kelompok besar etnis Dayak di Kalimantan Barat.

Terdapat ketidaksesuaian pada bab tiga dihalaman 55, materi interaksi masyarakat Dayak dengan Melayu, gambar menampilkan tradisi makan saprahan dalam masyarakat Melayu Sambas, sementara tradisi tersebut hanya di Sambas dan dilakukan pada saat upacara perkawinan sehingga tidak melibatkan orang Dayak secara utuh. Seharusnya gambar makan saprahan ditampilkan pada bab lima yaitu termasuk dalam budaya masyarakat Melayu Kalimantan Barat.

Dalam BSNP tentang komponen kelayakan isi yang mengenai mengandung wawasan kontekstual butir 2 (2006: 15), dijelaskan bahwa contoh-contoh yang disajikan memiliki keterkaitan logis dengan materi sajian. Pendukung penyajian materi yang benar adanya glosarium dan indeks. Dalam buku teks muatan lokal pendidikan multikultur Kalimantan Barat tidak ditunjukkan. Tujuan glosarium adalah memberi penjelasan arti istilah-istilah penting dalam teks dan ditulis secara alfabetis (BSNP, 2006 : 18). Indeks merupakan daftar kata atau daftar nama pengarang yang diikuti dengan nomor halaman kemunculan.

Terkait dalam menemukan materi sejarah 
pada buku teks muatan lokal pendidikan multikultur Kalimantan Barat, maka terlebih dahulu untuk mengetahui makna materi sejarah. Materi sejarah adalah bahan pelajaran yang diambil dari sumber-sumber sejarah yang terdiri dari sejarah lokal, sejarah sosial ekonomi, sejarah politik, sejarah agama, sejarah kota, sejarah desa, sejarah kebudayaan dan ditulis dengan berbagai pendekatan disiplin ilmu serta ditulis secara kronologis dan mengandung unsur masa lampau, waktu serta tempat peristiwa.

Materi sejarah yang terdapat pada buku teks muatan lokal pendidikan multikultur Kalimantan Barat, termuat di bab dua halaman 29 tentang masuknya orang-orang Melayu ke Kalimantan Barat dalam rangka melakukan penyebaran agama Islam. Selain itu juga ditunjukkan kerajaan-kerajaan bercorak Islam di Kalimantan Barat. Dilanjutkan pada halaman 33 tentang sejarah orang Tionghoa di Indonesia dan Kalimantan Barat.

Berkaitan dengan pengaruh dan peran orang-orang Tionghoa di Nusantara ketika itu yang menyebarkan agama Islam, disebutkan oleh beberapa dari Sunan atau Wali Songo yang berasal dari etnis Tionghoa, diantaranya Sunan Bonang (Bong Ang), Sunan Kalijaga (Gan Si Cang), Sunan Ngampel (Bong Swi Hoo), Sunan Gunung Jati (Toh A Bo) dan lainnya konon berasal dari Champa (Kamboja/ Vietnam), Manila dan Tiongkok. Pada masa Dinasti Ming (1368-1643), kekuatan armada yang dipimpin Laksamana Cheng Ho, membawa orang-orang Tionghoa dan menjalin hubungan dengan masyarakat lokal salah satunya adalah perkawinan.

Dari materi pada buku teks muatan lokal pendidikan multikultur, untuk materi sejarah yang dipaparkan masih sangat lemah, yang mengatakan bahwa Sunan atau Wali Songo berasal dari etnis Tionghoa. Ricklefs (2005 : 27) proses Islamisasi melalui dua tahapan secara umum, yaitu penduduk pribumi mengalami kontak dengan agama Islam dan kemudian memeluknya, orang asing Asia (Arab, India, Cina, dll) yang telah memeluk agama Islam tinggal secara menetap di suatu wilayah Indonesia, kawin dengan penduduk asli. Utusan-utusan dari Arab pada masa Khalifah Ut- sman (644-656) telah datang ke istana Cina, sehingga kontak Cina dengan dunia Islam telah terjaga lewat jalur perdagangan yang melalui perairan Indonesia. Besar kemungkinan terjadi Sunan atau Wali Songo merupakan orang-orang lokal hasil dari perkawinan para pedagang atau saudagar dari Arab. Kemudian nama pada beberapa Wali Songo seperti, Sunan Bonang (Bong Ang), Sunan Kalijaga (Gan Si Cang), Sunan Ngampel (Bong Swi Hoo) dan Sunan Gunung Jati (Toh A Bo), adalah sebutan dalam bahasa Cina, namun tidak berarti Sunan atau Wali ini berasal dari etnis Tionghoa.

Dari penyajian materi jelas ada beberapa kekurangan baik segi keruntutan konsep, penulisan keterangan rujukan pada ilustrasi, glosarium dan indeks. Tetapi penulisan yang berhubungan dengan materi sejarah masih banyak memiliki kelemahan, diantaranya tidak kronologis penyajian terutama yang berkaitan dengan peristiwa, seperti pada materi gambaran singkat etnis Melayu dalam bab dua halaman 29.

Menjelaskan bahwa orang Melayu datang ke Kalimantan sekitar abad ke-14 akhir yang disebabkan oleh adanya peran Kerajaan Sriwijaya dan Majapahit yang ketika itu membawahi beberapa kesultanan atau kerajaan di Kalimantan.

Materi tersebut membingungkan karena menyebutkan kesultanan dan tentunya pasti kerajaan bercorak Islam. Namun pada abad ke-14 di Kalimantan belum terbentuk kerajaan bercorak Islam. Hal ini diperkuat oleh penjelasan Lontaan (1975 : 80) pada abad ke-14 di Kalimantan Barat terdapat Kerajaan Tanjungpura di Sukadana yang berdiri sekitar tahun 1400 M oleh Pangeran Prabu yang bergelar Raja Baparung dari ayah yang bernama Prabu Jaya putra dari raja Majapahit.

Semestinya dalam bab dua halaman 29 pada buku teks muatan lokal pendidikan multikultur Kalimantan Barat, pada bagian awal menjelaskan eksistensi Kerajaan Sriwijaya dan Majapahit yang memiliki kekuatan militer terutama armada lautnya sehingga mampu menaklukkan seluruh kerajaan di Nusantara. Salah satunya kerajaan-kerajaan yang terdapat di Kalimantan Barat. Dengan 
runtuhnya Kerajaan Majapahit pada akhir abad 14 maka membuka peluang bagi kerajaan yang di bawah kekuasaan Majapahit memberontak dan diantaranya membentuk kerajaan yang bercorak Islam.

Pada bab lima halaman 73 yang menjelaskan budaya masyarakat Melayu Kalimantan Barat, yakni tradisi Meriam Karbit yang merupakan manifestasi dari proses berdirinya Kerajaan Pontianak pada tahun 1771. Sedikit menyinggung materi sejarah dan sumber data pendukung yang tidak lengkap, terlalu banyak memaparkan kisah atau cerita rakyak (folklore) yang mengandalkan mistik sehingga fakta-fakta sejarah menjadi tidak utuh.

Kemudian pada bab tujuh halaman 96 buku teks menjelaskan materi mengenai asal usul Karapan Sapi, yang dipelopori oleh Raja Sumenep yang bernama Raden Temor bergelar Raja Socadiningrat III. Ketika itu melakukan perjalanan keliling Madura dan ketika itu ada sapi yang lepas sehingga membuat perhadian raja dan ikut serta untuk menangkap sapi tersebut. Tanpa sengaja sang raja mencoba untuk merasakan proses membajak sawah, ketika itu muncul ide untuk menghibur rakyatnya dengan menggelar perlombaan sapi yang menggunakan klekes tanpa mata bajak, sehingga tradisi tersebut dinamakan Karapan Sapi.

Materi yang disajikan tersebut memiliki kekurangan yakni tidak menunjukkan keterangan waktu, sumber data dan lebih menekankan pada sejarah lokal masyarakat Madura. Taufik Abdullah (2005 : 16) menjelaskan, sejarah lokal bisa mencakup peristiwa-peritiwa penting yang memiliki kaitan dengan sejarah nasional dan peristiwa-peristiwa khas lokal. Sedangkan aspekaspek kajian sejarah lokal diantaranya mencakup kebudayaan yang berupa kreativitas manusia dalam bentuk cara berpikir, nilainilai, kepercayaan, ideologi, kearifan dan tradisi lokal (Taufik Abdullah, 2005 : 20).

Materi sejarah yang ada dalam buku teks muatan lokal pendidikan multikultur Kalimantan Barat, termasuk ke dalam sejarah lokal dan sejarah kebudayaan. Sejarah lokal adalah suatu bentuk penulisan sejarah dalam lingkup yang terbatas yang meliputi suatu lokalitas tertentu. Sejarah lokal diartikan sebagai studi tentang kehidupan masyarakat atau khususnya komunitas dari suatu lingkungan sekitar (neighborhood) tertentu dalam dinamika perkembangannya dalam berbagai aspek kehidupan manusia.

Sasaran pokok (subject matter) sejarah lokal, yang dengan jelas memberi pembatasan geografis dari ruang lingkupnya, sering sekali berkaitan erat dengan sejarah sosial (Taufik Abdullah, 1985 : 20). Salah satu pendekatan yang digunakan dalam penulisan sejarah lokal adalah pendekatan sejarah sosial. Sejarah lokal harus memperhitungkan dan mempertimbangkan dengan baik ikatan struktural, yaitu jaringan peranan sosial yang saling bergantungan, terhadap aktor sejarah lokal setempat.

Penulisan sejarah lokal selalu mengaitkan antara gejala yang terjadi dimasyarakat sekarang dengan struktur sosial kebudayaan sebelumnya. Sejarah lokal sangat erat kaitanya dengan tradisi lisan. Tradisi lisan menyangkut pesan-pesan yang berupa pernyataan-pernyataan lisan yang diucapkan, dinyanyikan melalui musik atau alat bunyibunyian. Pada buku teks muatan lokal pendidikan multikultur Kalimantan Barat, memuat materi sejarah lokal yang di dalamnya menguraikan bagian-bagian dari sejarah kebudayaan.

Sejarah kebudayaan mengulas tentang peristiwa atau kisah yang ditimbulkan oleh manusia dilampau dibidang kebudayaan dan perkembangan dari masa ke masa (Sri Wahyuning, 1990 : 21). Dalam sejarah kebudayaan, materi yang diajarkan adalah kebudayaan-kebudayaan yang lampau dalam pertumbuhan dan perkembangannya dari masa ke masa (Soekmono, 1973 : 14). Nampak bahwa konteks sosial-kultur etnis yang ada di Kalimantan Barat disusun dengan sebaik mungkin dalam buku teks, sehingga peristiwa-peristiwa di masa lampau menjadi tinggi maknanya dan memiliki nilai historis tersendiri. 


\section{SIMPULAN}

Kalimantan Barat sejak tahun 1962 sampai dengan 1999 pernah mengalami 14 kali konflik etnis yang melibatkan etnis Dayak, Melayu, Tionghoa dan Madura. Berdasarkan pengalaman masa lalu beberapa lembaga swadaya masyarakat di Kalimantan Barat melakukan berbagai sosialisasi, seminar kepada pemerintah dan tokoh-tokoh masyarakat untuk mencapai rekonsiliasi konflik.

Institut Dayakologi, Lembaga Gemawan, Sekretariat Segerak Pancur Kasih, Mitra Sekolah Masyarakat (MiSEM), Badan Koordinasi Koperasi Kredit Daerah (BK3D) Kalimantan Barat dan PEK-Pancur Kasih, sepakat untuk mendirikan aliansi strategis yang dinamakan ANPRI (Aliansi untuk Perdamaian dan Rekonsiliasi) yang disokong oleh CCFD (Comite Catholique la et Pour le Developpment) dari Francis dan Cordaid (Catholic Organisation for Relief and Development) dari Belanda, kedua lembaga tersebut adalah lembaga yang berasal dari misi Katholik yang bergerak dibidang sosial dan kemanusiaan.

Salah satunya adalah untuk perdamaian daerah-daerah konflik yakni Kalimantan Barat. Isu yang dijadikan sumber dalam pembahasan ANPRI adalah multikultural Kalimantan Barat. Proses pelaksanaan pengenalan dan penanaman multikultural melalui jalur pendidikan yang dipilih adalah Sekolah Menengah Pertama (SMP).

Sumber belajar yang digunakan dalam proses menunjang pembelajaran di sekolah salah satunya buku teks. ANPRI bekerjasama dengan sekolah-sekolah melalui seminar dan sosialisasinya dilaksanakan dengan membuat buku teks muatan lokal pendidikan multikultur Kalimantan Barat.

Tujuan dimunculkannya buku teks muatan lokal pendidikan multikultur Kalimantan Barat adalah untuk rekonsiliasi konflik dan pengenalan serta penanaman kembali pengetahuan tentang budaya etnis yang ada di Kalimantan Barat. Nilai-nilai budaya dalam multikultural mengandung unsur keluhuran yang tinggi dan harus dikenalkan dan ditanamkan dalam diri siswa sejak dini. Kemudian buku teks muatan lokal pendidikan multikultur SMP di Kalimantan Barat adalah bagian dari proses rekonsiliasi konflik yang selama ini sering terjadi di Kalimantan Barat.

Buku teks muatan lokal pendidikan multikultur lebih banyak menyajikan materimateri yang berasal dari etnis Dayak, Melayu, Tionghoa dan Madura, sedikit ditambahkan dengan etnis-etnis lain seperti Jawa, Bugis. Silabus menunjukkan Standar Kompetensi (SK) mengenai konsep dasar dan arti penting pendidikan multikultur, mengenal dan memahami kondisi bahwa Kalimantan Barat sebagai wilayah yang multikultural serta menjadikan materi multikultural sebagai sumber inspirasi untuk memajukan Kalimantan Barat.

Kompetensi Dasar (KD) terbagi dalam tujuh bab dengan 115 halaman. Kelayakan isi materi dalam buku teks muatan lokal pendidikan multikultur menunjukkan keluasan dan kedalaman materi, fakta yang disampaikan sesuai dengan kenyataan yang digambarkan melalui contoh-contoh, materi disesuaikan dengan perkembangan ilmu pengetahuan sehingga menumbuhkan semangat keingintahuan peserta didik untuk lebih mempelajari buku teks.

Menggunakan penulisan bahasa Indonesia namun beberapa materi ada menggunakan istilah asing seperti akulturasi, inkulturasi, asimilasi, integrasi dan amalgasi. Selain itu ada juga menggunakan istilah atau bahasa daerah guna memperjelas materi yang dimaksud, seperti penyebutan pesta panen padi masyarakat Dayak (Dange, Ngabayotn, Nyabakng dan Naik Dango). Kalimat masih belum lugas, tampak pada penjelasan pengertian pendidikan multikultur. Selain itu, dalam buku teks muatan lokal pendidikan multikultur Kalimantan Barat menunjukkan konsistensi dalam penggunaan istilah.

Teknik penyajian buku teks muatan lokal pendidikan multikultur Kalimantan Barat memiliki kekurangan menurut buku panduan instrumen penilaian buku teks (BSNP). Bab satu tidak ada pendahuluan sebagai pengantar namun terintegrasi dalam materi bahasan. Kesesuaian ilustrasi dan penggunaan tabel disajikan buku teks muatan lokal pendidikan multikultur. 
Ketidaksesuaian materi ditemukan pada bab tiga di halaman 55, mengenai interaksi masyarakat Dayak dengan Melayu, yang menampilkan gambar tradisi makan saprahan. Sementara tradisi tersebut hanya di Sambas dan dilakukan saat upacara perkawinan sehingga tidak melibatkan orang Dayak secara utuh.

Seharusnya gambar tradisi makan saprahan ditampilkan pada bab lima, termasuk dalam budaya masyarakat Melayu Kalimantan Barat, sehingga antara gambar dan materi memiliki kesesuaian. Buku teks tidak menunjukkan glosarium dan indeks. Penyajian pembelajaran berpusat pada peserta didik dengan memberi pengalaman untuk membuat karya berupa lampion, miniatur rumah adat Dayak, kliping tentang upacara ada masyarakat Dayak, kliping tentang permainan Barongsai setiap akhir bab peserta didik disediakan soal-soal atau pertanyanpertanyaan untuk mengetahui pemahaman peserta didik terhadap materi yang telah diajarkan.

Materi dalam buku teks muatan lokal pendidikan multikultur sangat beragam, terutama memperkenalkan gambaran singkat etnis-etnis yang ada di Kalimantan Barat dan budaya yang dimiliki oleh setiap etnis. Materi diperkaya dengan budaya dan bahasa dari setiap etnis semakin membuat buku teks tersebut asyik untuk dibaca dan dipelajari siswa.

Materi sejarah yang termuat dalam buku teks muatan lokal pendidikan multikultur adalah sejarah lokal Kalimantan Barat dan sejarah kebudayaan etnis. Pendekatan sejarah sosial lebih mendominasi karena bahasan sosio-kultur dari berbagai etnis di Kalimantan Barat cenderung tampak dalam setiap pembahasan. Namun dalam penyajian materi sejarah banyak yang belum kronologis, sistematis, tidak menunjukkan waktu dan sumber yang jelas.

\section{UCAPAN TERIMA KASIH}

Terima kasih kepada semua pihak yang turut membantu proses penulisan artikel ini serta kepada redaktur yang memuat hasil artikel. Semoga dapat memberikan kontribusi bagi dunia pendidikan.

\section{DAFTAR PUSTAKA}

Abdullah, Taufik. 1985. Sejarah Lokal Di Indonesia. Yogyakarta: Gadjah Mada University Press dan Susanto Zuhdi. 2005, Pedoman Penulisan Sejarah Lokal, Asdep Urusan Sejarah Nasional Deputi Bidang Sejarah dan Purbakala. Kementerian Kebudayaan Dan Pariwisata.

Badan Standar Nasional Pendidikan (BNSP). 2006. Instrumen Penilaian Tahap II Buku Teks Pelajaran Pendidikan Dasar dan Menengah. Jakarta.

M.C, Ricklefs. 2005. Sejarah Indonesia Modern 1200-2004. Jakarta: PT. Serambi Ilmu Semesta.

S., Sri Wahyuning. 1990. Sejarah Kebudayaan Kesenian Indonesia I : Sebelum Pengaruh Hindu Sampai Dengan Kebudayaan Indonesia Hindu. FKIP PIPS Sejarah. Departemen Pendidikan dan Kebudayaan Republik Indonesia. Universitas Sebelas Maret Surakarta

Sukmadinata, Nana Syaodih. 2000. Pengembangan Kurikulum Teori Dan Praktek. Bandung : Remaja Rosda Karya. 